\title{
IM. Terasaka : Untersuchung der Alkaloide der Wurzelrinde von Orixa japonica, Thunb. (III. Mitteil.)
}

[Aus der techn. Hochschule zu Tokushima]

(Eingegangen am 4. Sept. 1933)

Aus der Wurzelrinde von Orixa japonica, Thunb. hat Verf. laut einer früheren Mitteilung (Journ. of Pharm. Soc. Japan Nr. 595, 707) 2 neue Alkaloide, nämlich Orixin $\mathrm{C}_{18} \mathrm{H}_{23} \mathrm{NO}_{6}$ bezw. $\mathrm{C}_{18} \mathrm{H}_{21} \mathrm{NO}_{6}$ und Kokusagin $\mathrm{C}_{13} \mathrm{H}_{9} \mathrm{NO}_{4}$, isoliert. Sie sind sehr schwache Basen, deren Lösungen stark fluorescieren. Sie sind leichter der Entmethylierung zugänglich und sind dadurch charakteristisch, dass sie sich leicht isomerisieren. Insbesondere gibt Kokusagin beim Erhitzen mit Jodmethyl im Einschlussrohr ein $\mathrm{V}$ Methylderivat (Isokokusagin), wahrscheinlich in folgender Weise:

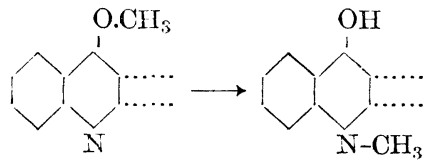

Aus Kokusagin entsteht durch Oxydation mit $\mathrm{KMnO}_{4}$ Phenolkarbonsäure. Andere Rutacenalkaloide, besonders Dictamnin bezw. Skimianin (Jour. of Pharm. Soc. Japan Nr. 586, 1117, 1133) zeigen auch solche Reaktionen. Bei der spektrographischen Prüfung des Kokusagin wurde vom Verf. die Absorptionskurve der beiden Substanzen d. h. Kokusagin, ferner Dictamnin bezw. Skimianin fast übereinstimmend befunden. Nur ist Kokusagin etwas bathochromischer als Dictamnin bezw. Skimianin. Da die teilweise abgelöste Konstitutionsformel des Kokusagin

$$
\mathrm{C}_{11} \mathrm{H}_{4}\left\{\begin{array}{l}
-\mathrm{OCH}_{3} \\
-\mathrm{O} \\
-\mathrm{O} \\
\mathrm{O} \\
\equiv \mathrm{O}
\end{array}\right.
$$




\section{0}

ist, scheint dessen Konstitution folgendermassen beschaffen zu sein :

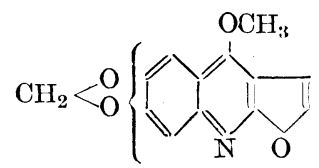

Diese Wurzelrinde enthält noch 2 neue Basen, die sich aus der dicken Flüssigkeit nach der Abscheidung der oben erwähnten Basen durch Erwärmen mit $\mathrm{HCl}$ auf dem Wasserbade isolieren lassen. Die eine, für welche Verf. den Namen Kokusaginin vorschlägt, bildet aus Alkohol farbund geschmacklose Prismen vom Fp. $171^{\circ}$ und entspricht der Zusammensetzung $\mathrm{C}_{14} \mathrm{H}_{13} \mathrm{NO}_{4}$ oder $\mathrm{C}_{14} \mathrm{H}_{15} \mathrm{NO}_{6}$. (Gef. : C 65,01 H 5,58 N 8,5. Ber.: C 64,86; 64,37 H 5,01; 5,75 N 5,4). Diese Base bildet Aurichloriddoppelsalz vom $Z \mathrm{p}$. $162-163^{\circ}$, ferner ein Platinchloriddoppelsalz vom Fp. $290^{\circ}$ und ein Pikrat vom Fp. $218^{\circ}$. Kokusaginin ist unlöslich in Petroläther und Wasser, allgemein löslich in organischen Solvenzien. Alle seine Lösungen zeigen eine violette Fluorescenz. Ferner löst es sich in der Hitze nicht in Wasser und Ätzalkalien. Weder mit konz. Schwefelsäure noch mit Salpetersaure gibt es eine Färbung. Es hat 3 Methoxylgruppen. Das vierte Sauerstoffatom sowie das Stickstoffatom verhalten sich indifferent. Durch verd. HCI lässt sich Kokusaginin nicht wie Orixin aufspalten, sonderen es netsteht dabei ein Chlorhydrat vom $\mathrm{Zp}$. $225^{\circ}$. Mithin kann Kokusaginin aufgefasst werden als

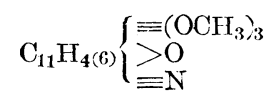

Nach spektrographischer Untersuchung, nach der die maximale Absorption bei der Frequenz von etwa 3200 und 4000, die minimale Adsorption bei der Frequenz von 3700 liegen, nähert sich Kokusaginin auch der Skimianinreihe und könnte mit Skimianin isomer sein.

Die andere Base, die Kokusaginolin genannt werden möge, bildet fast farb- und geschmacklose Prismen vom Fp. $283^{\circ}$ aus Alkohol. Diese Base $-3^{8}-$ 
wurde vorher durch wiederholte Fällung mit $\mathrm{HCl}$ gereinigt. Die Zusammensetzung entspricht der Formel $\mathrm{C}_{17} \mathrm{H}_{13} \mathrm{NO}_{5}+1 \frac{1}{2} \mathrm{H}_{2} \mathrm{O}$. (Gef. : $\mathrm{H}_{2} \mathrm{O} 8,08$; C 65,$18 ; \mathrm{H} 4,47 ; \mathrm{N} 4,47,4,50$. Ber.: $\mathrm{H}_{2} \mathrm{O} 8,01 ; \mathrm{C} 65,59 ; \mathrm{H} \mathrm{4,18;} \mathrm{N}$ 4,50). Kokusaginolin ist unlöslich in Petroläther und Wasser, schwerlöslich in Alkohol.

In alkoholischer Lösung zeigt es blauviolette Fluorescenz. Es löst sich in Alkalikarbonat und Ätzalkalien. Der Titration nach ist es nicht anders als eine Phenolbase, obgleich es durch Eisenchlorid keine Farbreaktion gibt. Mit konz. Schwefelsäure gibt es eine grüne, mit konz. Salpetersäure eine schwach orangerote Färbung. Es reduziert weder die Fehlingsche Lösung noch reduziert Permanganat in der Kälte. Es hat keine Karbonyl- oder Methylengruppe und keinen Laktonring, hat aber 3 Methoxylgruppen. Durch Essigsäureanhydrid entsteht die Acetylverbindung $\mathrm{C}_{1-} \mathrm{H}_{12} \mathrm{NO}_{5} \cdot \mathrm{COCH}_{3}$ vom Fp. 172,5 . Da die Liebermannsche Nitrosoreaktion negativ ist, ist es cine tertiäre Base. Spektrographisch scheint es zu derselben Reihe der übrigen Basen anzugehören. Es hat viel Ähnlichkeit mit der Phenolbase aus Orixin.

Verf. hat ferner aus derselben Rinde eine in Chloroform lösliche Substanz, die in farblosen Tafeln kristallisiert (Fp. 252,5\%), vermutlich ein Lakton, extrahiert. Die Zusammensetzung ist $\mathrm{C}_{16} \mathrm{H}_{18} \mathrm{O}_{6}$. Sie ist schwerlöslich in Alkohol, Eisessig, aber unlöslich in der Kälte in Alkali. Sie besitzt werder Methoxyl- noch Karbonylgruppen, gibt aber die Göbelsche Reaktion, gibt aber durch Essigsäureanhydrid eine Acetylverbindung vom Fp. $122^{\circ}$. 
1046 寺阪: コクサギ Orixa japonica, Thunb. 根皮のアルカロイド研究(第三報)

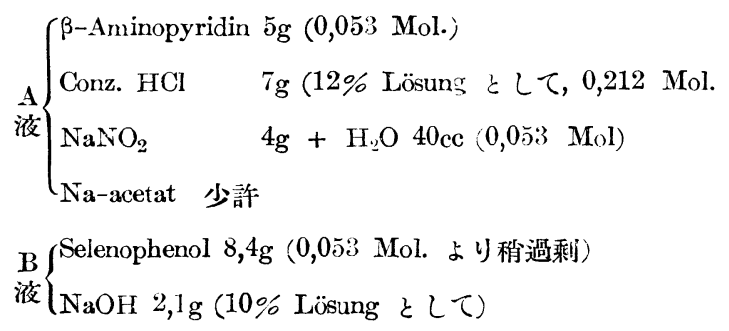

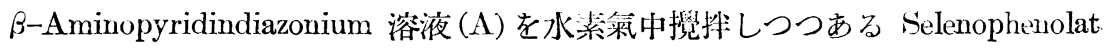

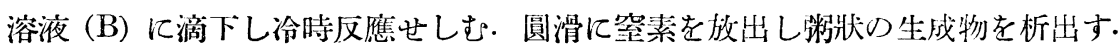
反應液を $\mathrm{HCl}$ 酸性となし一旦 Aether にて振波し副生せる Bisphenyldiselenid を溶取し去る・水層を分取し Na-acetat を加へ無機酸を山和し更に $\mathrm{NaHCO}_{3}$ に て微アルカリ性となし充分 Base を遊離せしむ. 夫を Aether にて溶取し數回水 洗後芒硝にて乾燥し，Rückstand を精溜に附す. $\mathrm{K}_{\mathrm{p}_{15}} 128^{\circ}$ ，無臭黄色液體 $1 \mathrm{~g}$ を 得たり. 得量 $8 \%$ (理論).

水, 稀醋酸不溶, 䃘酸, Aether, Chloroform 易溶. $\mathrm{HCl}$ 呼潮解性.
0,2004 Sbst.: Se 0,0360-
Gef. Se $32,94 \%$
$\mathrm{C}_{11} \mathrm{H}_{9} \mathrm{SeN}$
Ber. Se $33,82 \%$

\title{
コクサギ Orixa Japonica, Thunb. 很皮の アルカロイド㸴究（第三報）
}

\author{
寺阪 正 信
}

(德島高等工業學校製薬化學教空)

(昭和 8 年 9 月 1 日受理)

M. Terasaka: Untersuchung der Alkaloide dir

Wurzelrinde von Orix japonica. Thumb.

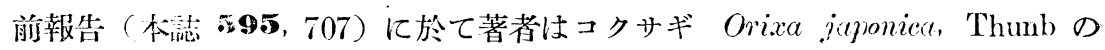
根皮より 2 種のアルカロイドを抽出して Orixin 及 Kokusagin と命名し夫ょ集 成を $\mathrm{C}_{18} \mathrm{H}_{23} \mathrm{NO}_{6}$ (或は $\mathrm{C}_{18} \mathrm{H}_{21} \mathrm{NO}_{6}$ ) 及 $\mathrm{C}_{14} \mathrm{H}_{9} \mathrm{NO}_{4}$ と定めその諸性質在研究せり. その際コクサギンの性狀が他の芸香料アルカロイドなるヂクタムニン, スキミア 
寺阪：コクサギ Orixa japonica, Thunb. 根皮のアルカロイド研究 第三報) 1047

ニンと酷似するものあることを指摘せるが今包スペクトル吸收曲線を作成し之を 比較するに及びその確信を深むるに至ると其に更に 2 種のアルカロイドを抽出し 得をるを以て玆に報告せんとす。

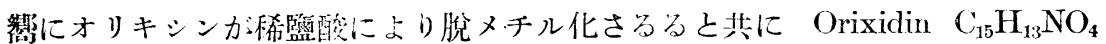

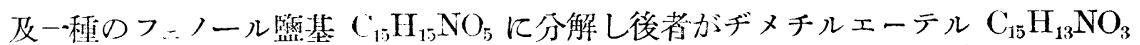

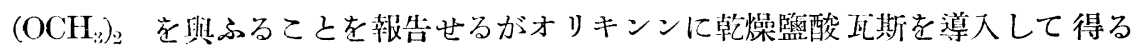

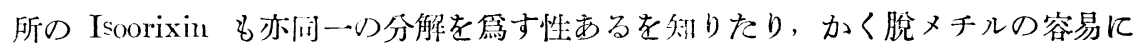
行はるるとと・コクサギンが常涯に於てョードメチルと作用せずして関管中凡そ $100^{\circ}$ に於て始めて作用すると共に恐らく Methoxylchinolin 型より $\mathrm{N}$-methylchinolon 型に埋性化し.

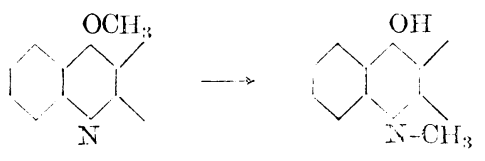

Isokokusagin の生成する事實は盬基 性の極めて微弱なるを示し溶液が著し く篮石彩を呈し且アアセン中過マンガ

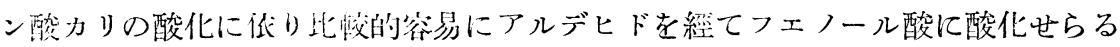

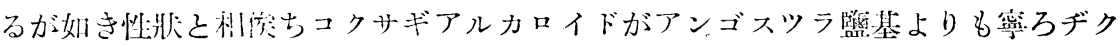
タムニン・スキミアニンと齐近なる關係にあるべしと像想せり，酒精溶液に於ける スペクトル吸收曲線を比粐するに略同一の選擇的吸收を示しコクサギンの少しく bathochromisch なる蕰にするのみ (Fig. 1.). てれ恐らく助色圍をるメチレン

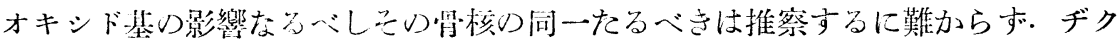

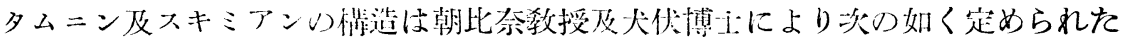

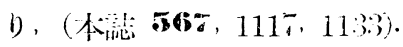
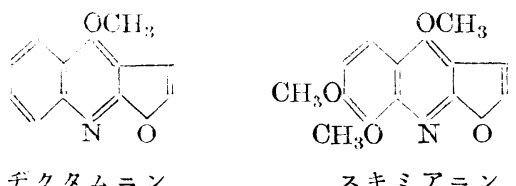

而してコクサギンの部分的構造は

$$
\mathrm{C}_{11} \mathrm{H}_{4}\left\{\begin{array}{l}
-\mathrm{OCH}_{3} \\
-\mathrm{O} / \mathrm{O}>\mathrm{CH}_{2} \\
-\mathrm{O}
\end{array}\right.
$$


1048 寺阪：コクサギ Orixa japonica, Thunb. 棑皮のアルカロイド砸究(第三報)

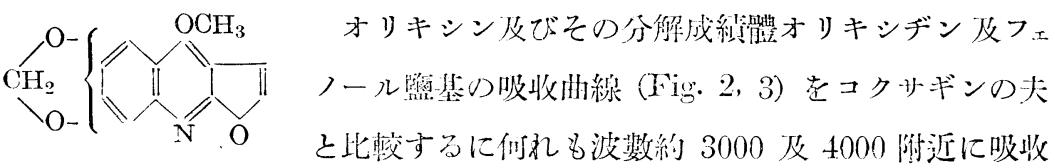

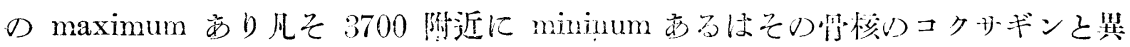
る甚しからざるるのある立示す似似たり。

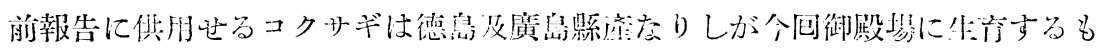

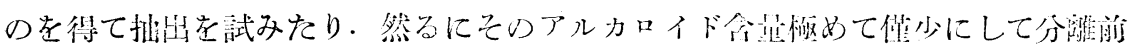

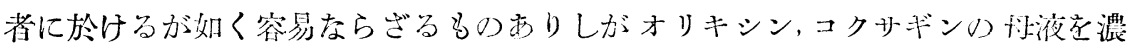

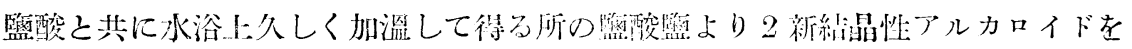

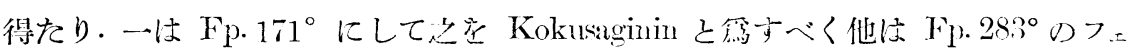
フール籃基にして之を Kokusaginolin と第さんとす。

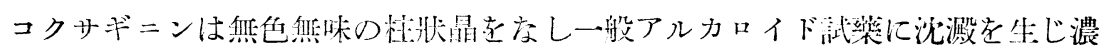

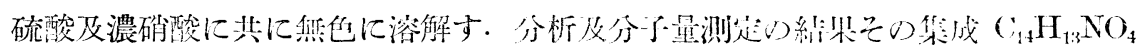
或は $\mathrm{C}_{14} \mathrm{H}_{15} \mathrm{NO}_{4}$ 相賞す. 石沮エーテルに不浴にしてェーテル，アルコール，クロ

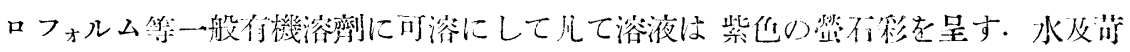

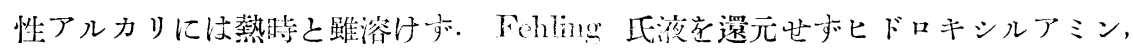

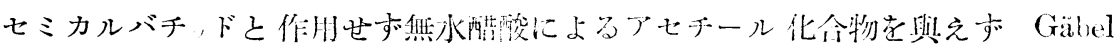

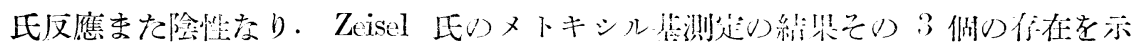

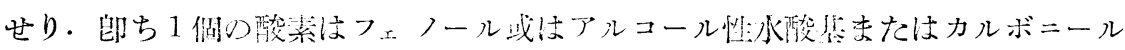

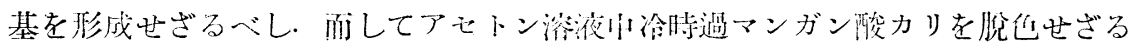

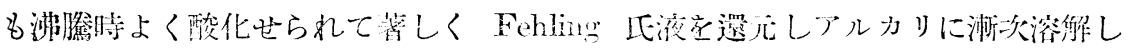

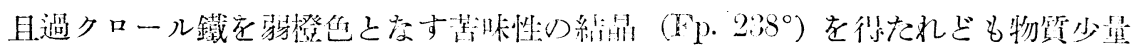

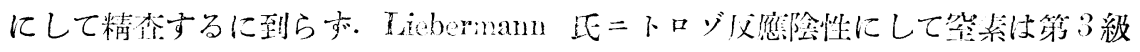

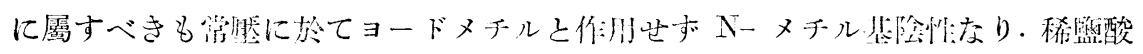

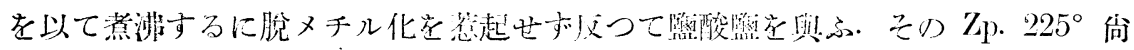

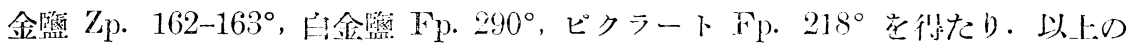
諸性筫よりコクサギニンの嘼分的櫵造は

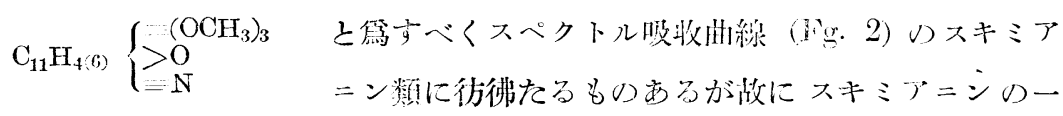

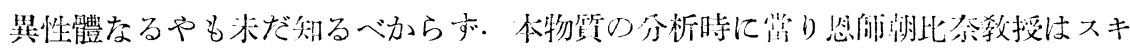


寺阪：コク年ギ Orixa japonica, Thunb. 根皮のアルカロイド研究(第三報) 1049

ミアニン相品 $\left(\mathrm{Fp} \cdot 171^{\circ}\right)$ と混融の營をとられその Fp. 131 にして之と同一物

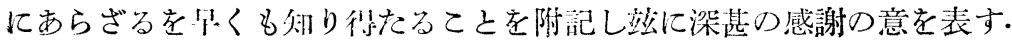

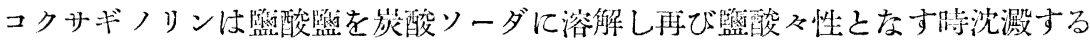

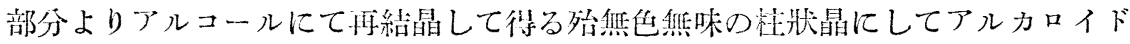
試藥に依り沈澱を生じ濃硫酸にて綠也，濃确酸にて微汇橙赤色に溶解す。分析及分

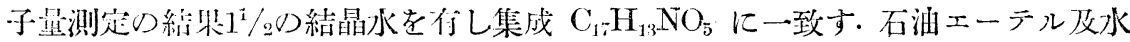
に不溶,アルコールに難浴にしてアルコール溶液は籃紫色の罃石彩を呈す。過ク口

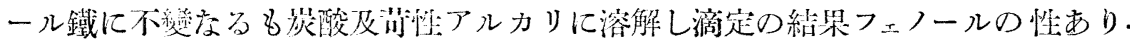

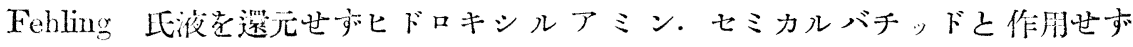
Goebel 纸㴧陰性疼り,從て finktioniert のカルボニール基及メチレンオキシド 基你在せす.ＺＺisel 氏法は 2 僻のメトキシル基の存在を示し無水醋酸によるアセ

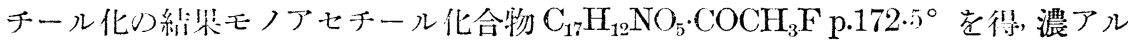

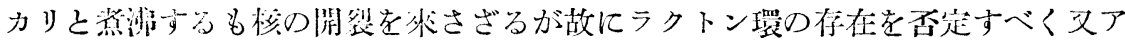

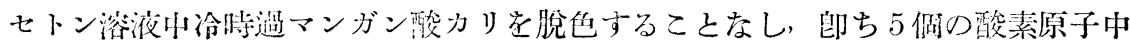

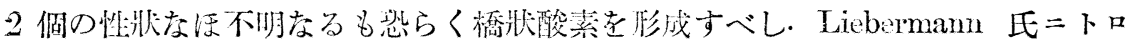

Fig. 1. Frequenz.

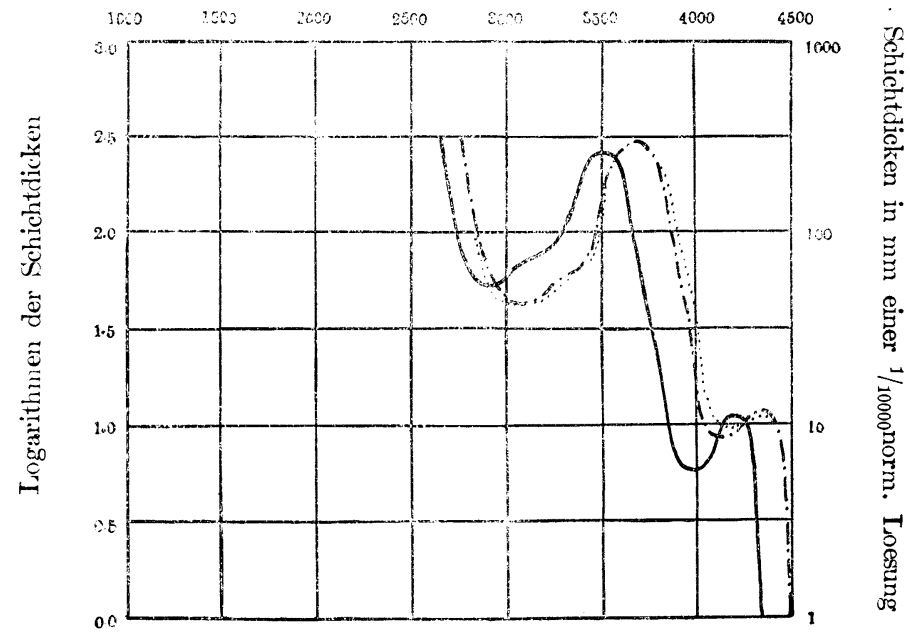

Kokusagin

Skimianin

Dictamnin 
1050 寺阪：コクサギ Orixa japonica, Thunb. 根皮のアルカロイド研究(第三報)

Fig.2. Frequenz.

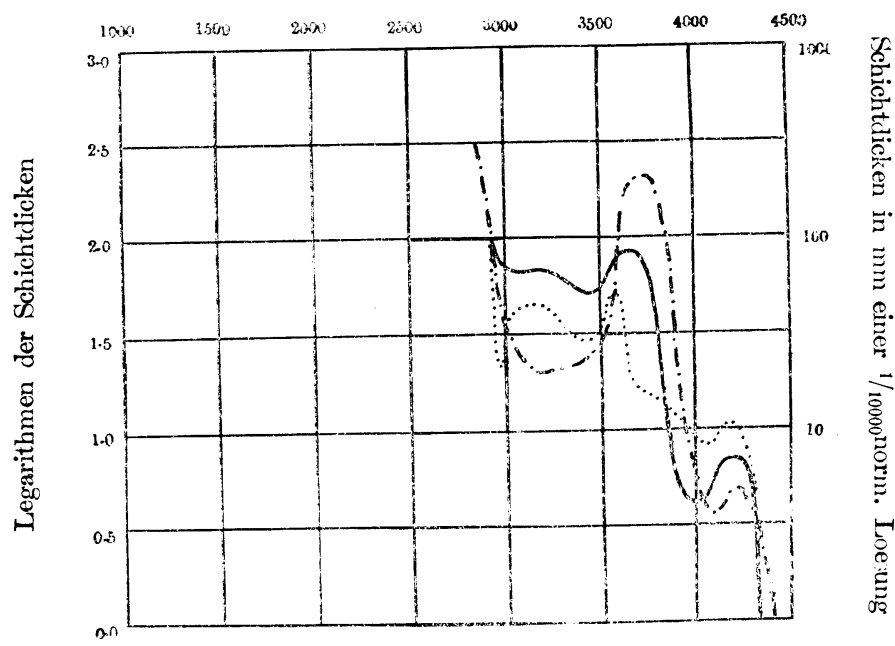

Orixin

Kokusaginin

Orixidin

Fig.3. Frequenz.

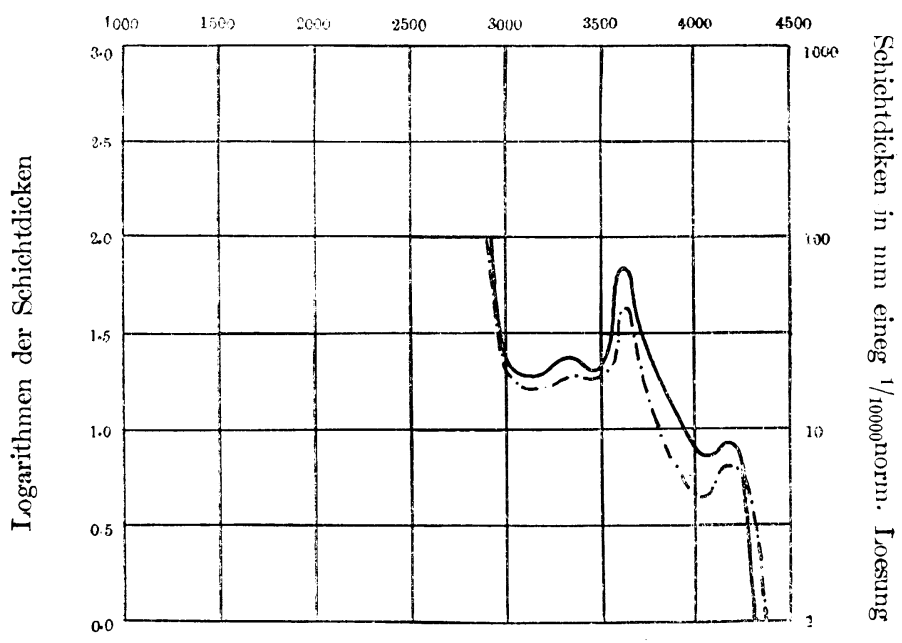

Phenolbace

Kokusaginolin 
寺阪：コクサギ Orixa japonica, Thunb. 根皮のアルカロイド研究(第三報) 1051

ゾ反應は陰性にして窒素は第 3 級に屬せん要するに本物質は次の如く表示し得心

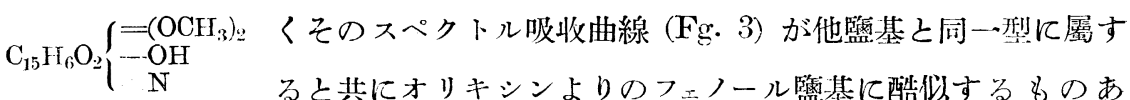
るは興味あり.

份德岛產コクサギ根皮よりは少量の無窒素性物質を得たり.Fp. $252.5^{\circ}$ の無色の 板狀晶にしてクロロフォルムに可溶, アルコール, 水醋に難溶なり. 蓺湯及冷アル カリに不溶なるが熱アルカリに溶解しラクトンの性あるが如し. 集成 $\mathrm{C}_{16} \mathrm{H}_{18} \mathrm{O}_{6}$ に 當る・メトキシル基を有ぜるる Goebel 氏反應陽性にしてメチレンオキシド基 を倠し义斯水醋酸に上りアセチール化合物 Zp 122。专作るが故に少くとも 1 個 のアルコール性水酸基を份すべし. Fehling 氏液の還元, ヒドロキシルアミンの作 用, 冷時逓マンガン酸カリの脫色等行はれず.

本矽究は佾䋶行中なり.

\section{實 驗 の 部 \\ イソオリキシンに對する稀監酸の作用}

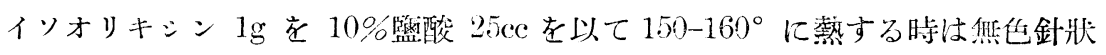
の結晶を析出す, Fp. 195゚にしてオリキシンより得るオリキシヂンと混融するも 融點の降下を來さ和又母液よりはZp. $113^{\circ}$ のフールール酸基を得てれ亦オリキシ ンより得るものと同一物なり。

$$
\text { アルカロイドひ抽出及分離 }
$$

原料植物は今回は靜岡䅫御殿場町附近より仰ぎをり。然るにそのアルカロイド 含量甚偉少にして分離法從て少しく前報告と異るものあり．細挫せる根皮をメタ ノールにて溫浸するてと 4 司, 溫时滤過し滤液よりメタノールを減壓にて溜去し 得たる越幾斯を $2 \%$ 硫酸にて $2-3$ 回溫浸, 冾後樹脂樣物質を濾別し赤褐色透明な る滤液アムモニア・アルカリ性となしェーテルにて數回振盜しェーテル鹰を洗滌

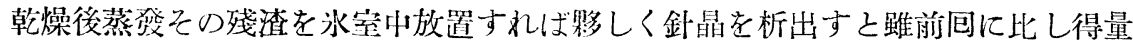
に泛しくクロロフォルムよる分劃絬白法效を奏し難く壓滤の後水醋・水・酒精等 にて繰返し再絬晶を經始めて統白忙壯濃硫酸に椳實赤色を呈するオリキシン(Fp. $\left.152.5^{\circ}\right)$ を得. その舽よりは前回同栐處理し絹絲狀に結晶するコクサギン ( Fp. $201^{\circ}$ )を得をり。

兩監基の母液は濃縮の後通常の溶劑を以て處理するも結晶析出せず．然るに稠 
1052 寺阪：コクサギ Orixa japonica, Thunb. 根皮のアルカロイド矿觉(第三報)

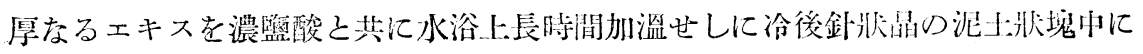

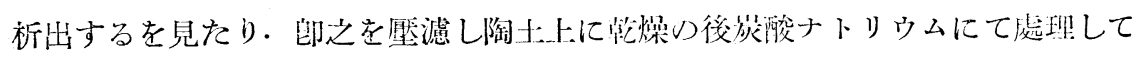
之に不溶の部它水に浮遊せしめアムモニア・アルカリ性となしェーテルにて再三

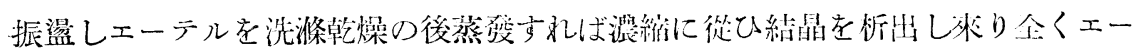

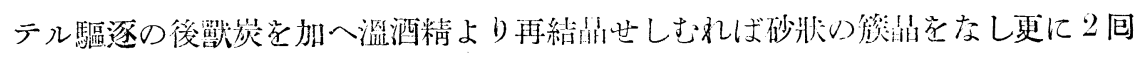

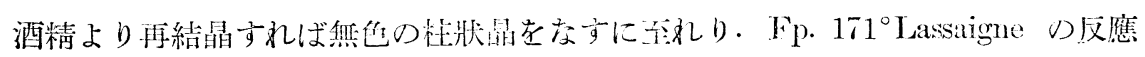

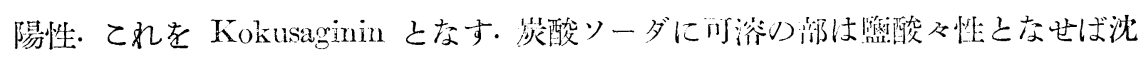

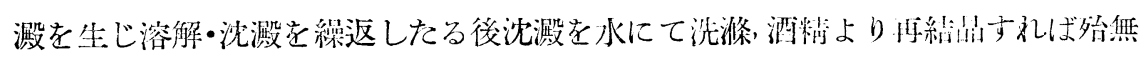

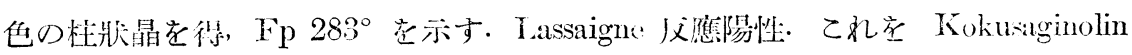
となす。

$$
\text { コクサギニンの性狀及分析 }
$$

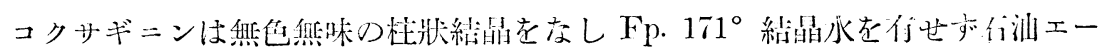

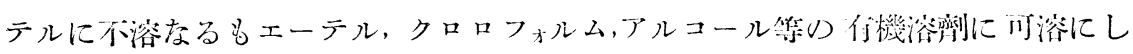

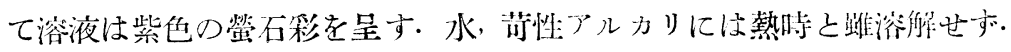

呈色反應

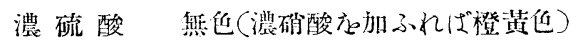

發烟㗂酸無色

元素分析

\begin{tabular}{|c|c|c|c|c|c|}
\hline 物質 & $0.1120 \mathrm{~g}$ & $\mathrm{CO}_{2} 0,2679 \mathrm{~g}$ & $\mathrm{H}_{2} \mathrm{O} \quad 0.0 .58 .5 \mathrm{~g}$ & Cóo 65.23 & $\mathrm{H} \% \mathrm{o}$ \\
\hline , & $0.1098 \mathrm{~g}$ & , $\quad 0.2608 \mathrm{~g}$ & $0.0 .54 \mathrm{dg}$ &, 64.78 & , \\
\hline , & $0.1120 \mathrm{~g}$ &, $0.2668 \mathrm{~g}$ & $0.0 .581 \mathrm{~g}$ & , 64.97 & , \\
\hline " & $0.1092 \mathrm{~g}$ &, $0.2604 \mathrm{~g}$ & $0.0 .54 \mathrm{~g}$ &., 65.04 & ” \\
\hline ", & $0.1221 \mathrm{~g}$ & $6.0 \operatorname{ccN}\left(30^{\circ}\right.$ & $766 \mathrm{~mm})$ & & N? \\
\hline , & $0.1224 \mathrm{~g}$ & $6.0 \mathrm{ccN}\left(31^{\circ}\right.$ & $76(6 \mathrm{~mm})$ & & " \\
\hline & $\mathrm{C}_{14} \mathrm{H}_{13} \mathrm{NO}_{4}$ & としての理論數 & Cóó 64.86 & Hоó 5.01 & No, \\
\hline & $\mathrm{C}_{14} \mathrm{H}_{15} \mathrm{NO}_{4}$ & " & C\% 64.97 & $1[960.75$ & $N \%$ \\
\hline
\end{tabular}

分子量测定(Rast 法)

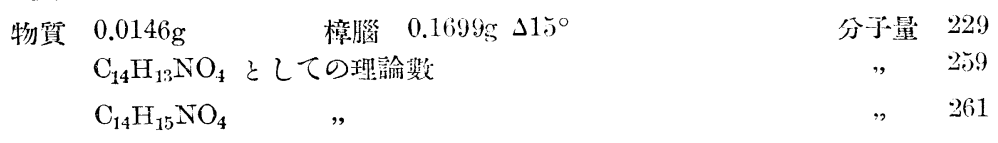

メトキシル基定量 (Zeisel 法)

物貿 $0.0355 \mathrm{~g}$

$\lg J 0.0952 \mathrm{~g}$

$\mathrm{CH}_{3} \mathrm{O} \%$ ó 35.36

$\mathrm{C}_{11} \mathrm{H}_{4} \mathrm{NO}\left(\mathrm{OCH}_{3}\right)_{3}$ としての理論薮

, $\quad 35.91$

$\left.\mathrm{C}_{11} \mathrm{H}_{6} \mathrm{NO}_{(} \mathrm{OCH}_{3}\right)_{3}$

, 35.63 
㖊阪：コッサギ Orixa japonica, Thunb. 根皮のアルカロイド研究(第三報) 1053

Nーメチル基の测足 (Herzig-Meyer 法)

陰性なり

定性的諸反應

過マンガン酸加里(アセトン浴雄)

還元せず

Fehling 氏液

Goebel 氏反隹

Liebermann 氏ニトロゾ反隹

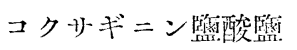

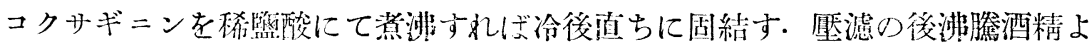
り2 包再結昆すれば輕き小柱狀晶として析出 $215^{\circ}$ にて緮少 $225^{\circ}$ にて分解す・水 にて薏沸すれば们ちにコクサギニンに復躋す。

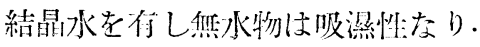

分析

$$
\begin{aligned}
& \text { 物筫 } 0.0691 \mathrm{~g} \\
& \mathrm{AgCl} \quad 0.031 \mathrm{ig} \\
& \mathrm{Cl} \% \quad 11.40 \\
& \mathrm{C}_{14} \mathrm{H}_{13} \mathrm{NO}_{4} \text { • } \mathrm{FlCl} \text { としての理論装 } \\
& \text {, } 12.35 \\
& \mathrm{C}_{14} \mathrm{Ir}_{15} \mathrm{NO}_{4} \cdot \mathrm{IfCl} \\
& , \quad 11.93
\end{aligned}
$$

結晶水の测分

$$
\begin{aligned}
& \text { 物额 } 0.1851 \mathrm{~g} \\
& \mathrm{H}_{2} \mathrm{O} \quad 0.0155 \mathrm{~g} \\
& \mathrm{C}_{14} \mathrm{H}_{13} \mathrm{NO}_{4} \cdot \mathrm{HCl} \cdot 11 / 2 \mathrm{H}_{2} \mathrm{O} \text { として0)理新侖数 } \\
& \mathrm{H}_{2} \mathrm{O} \% 8.37 \\
& \mathrm{C}_{14} \mathrm{H}_{15} \mathrm{NO}_{4} \cdot \mathrm{HCl} \cdot 11 / 2 \mathrm{H}_{2} \mathrm{O} \\
& \text {, } 8.37 \\
& \text {, } \quad 8.32 \\
& \text { コクけギニン金監 }
\end{aligned}
$$

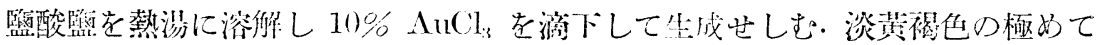

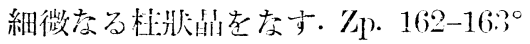

分析

$$
\begin{aligned}
& \text { 物留 } 0.0647 \mathrm{~g} \\
& \text { Au } \quad 0.0209 \mathrm{~g} \\
& \text { Aứ } \quad 32.30
\end{aligned}
$$

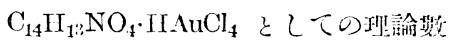

$$
\begin{aligned}
& \text {, } \quad 32.89 \\
& \mathrm{C}_{14} \mathrm{H}_{15} \mathrm{NO}_{4} \cdot \mathrm{HCLLuCl}_{3} \\
& \text {, } \quad 32.78 \\
& \text { コクサギニン白金監 }
\end{aligned}
$$

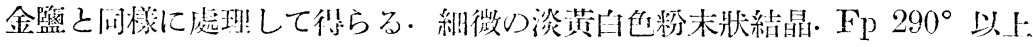

$$
\text { コクサギニンのピクラート }
$$

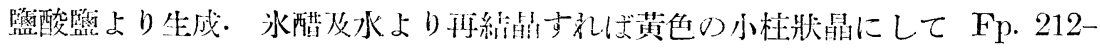
$213^{\circ}$ 
1054 寺阪：コクサギ Orixa japonica, Thunb. 根皮のアルカロiド研究(第三報)

コクサギニンに對するヒドロキシルアミンの作用

コクキギニン $0.2 \mathrm{~g}$ を鹽酸ヒドロキシルアミン $0.15 \mathrm{~g}$, 醋酸ナトリウム $0.3 \mathrm{~g}$ と

共に $10 \mathrm{cc}$ の酒精溶液となし水浴上數時間作用せしめ冷後多量の水を加へて析出 する結晶を㲀滤し酒精及水より再結す. Fp. $170^{\circ}$ 原鹽基と混融するも融點降下な L.

份全く同樣に處理してセミカルバチ,ド在作用せしめしが原監基の復歸を見た b.

$$
\text { コクサギニンのアセチール化の試み }
$$

コクサギニン $0.5 \mathrm{~g}$ に對し $0.2 \mathrm{~g}$ の無水醋酸ソーダ及之を被ふに足る無水醋酸 を加へ銅銅上輕く竟沸するとと3 時間にして冷後多量の水を加へ析出する物質を 壓滤し酒精より再結晶せしめしものは Fp. $170^{\circ}$ にてコクサギニンに他ならず。 コクサギノリンの性狀及分析

コクサギノリンは殆無色無味の細微の杜狀晶をなし Fp $283^{\circ}$ 結晶水を有す(石 油エーテル, ェーテル及水に不溶にして酒精に難溶苛性アルカリ及炭酸ソーダに 可溶なり．酒精溶液は藍紫色の營石彩を呈す。

呈色反應

漄硫酸綠色

發烟硝酸弱登赤色

元素分析

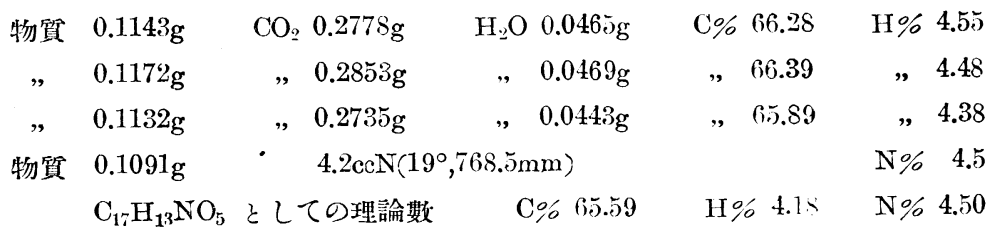

結晶水の定量

物質 $0.1240 \mathrm{~g}$

, $0.1276 \mathrm{~g}$

$\mathrm{C}_{17} \mathrm{H}_{13} \mathrm{NO}_{5}, 11 / 2 \mathrm{H}_{2} \mathrm{O}$ としての理論數
$\mathrm{H}_{2} \mathrm{O} \% \quad 7.82$

.8 .15

, $\quad 7.98$

分子量测定(Rast 法)
物筫 $0.0123 \mathrm{~g}$
樟腦 $0.1358 \mathrm{~g} \triangle 11.5^{\circ}$
分子量 315
$\mathrm{C}_{17} \mathrm{H}_{13} \mathrm{NO}_{5} \cdot 11 / .2 \mathrm{H}_{2} \mathrm{O}$ としての理論數
, 338 
寺阪：コクサギ Orixa japonica, Thunb. 根皮のアルカロイド研究(第三報) 1055

メトキシル基定量

物質 $0.0343 \mathrm{~g} \quad \mathrm{AgJ} \quad 0.0555 \mathrm{~g}$

$\mathrm{C}_{15} \mathrm{H}_{7} \mathrm{NO}_{5}\left(\mathrm{OCH}_{3}\right)_{3} \quad$ としの理論数

$\mathrm{CH}_{3} \mathrm{O} \% 21.36$

., $\quad 19.94$

定性的諸反應

過マンガン酸加里(アセトン溶液)

還元さず

Fehling 氏液

Goebel 氏反倠

陰性

Liebermann 氏反隼

$$
\text { コクサギノリンのアセチール化 }
$$

コクサギノリン $0.5 \mathrm{~g}$ に醋酸ソーダ $0.15 \mathrm{~g}$ を加へ無水醋酸 $5 \mathrm{cec}$ と銅網上弱く 煮沸するてと 2 洔間の後冷水を加ふれば直ちに結晶性析出物を生成す, 壓滤し十 分水洗の後陶土上に乾燥し酒精より再結晶せしむれば舆色の綿の如き針晶を得.

F $172.5^{\circ}$ 結晶水を侍せホ, 冷時アルカリに溶けホ酒精に難溶なり, 元素分析

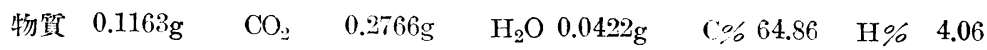

$\mathrm{C}_{17} \mathrm{H}_{12} \mathrm{NO}_{5} \cdot \mathrm{COCH}_{3}$ としての理論數

, $64.59 \quad, \quad 4.26$

コクサギノリンに對する濃厚カリ泈液の作用

コクサギノリン $0.2 \mathrm{~g}$ を濃原カリ腹液 $10 \mathrm{cc}$ を以て輕く堂沸せしむるてと 2 時

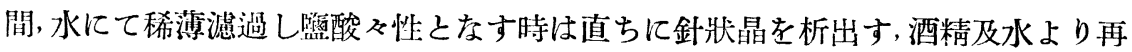
結晶せしめしものは Fp282 にして原監基に他ならず, ラクトン環は恐らく存在 せざらん。

コクサギノリンに對するヒドロキシルアミンの作用

コクサギノリン $0.5 \mathrm{~g}$ を践酸ヒドロキシルアミン $0.3 \mathrm{~g}$, 醋酸ソーダ $0.6 \mathrm{~g}$ と共 に酒精25cc に溶解せしめ水浴上數時間加溫の 後水にて稀薄すれば 細微の柱狀晶 を析出す, 酒精及水より再結晶したるものは Fp. $280^{\circ}$ にして原鹽基と混融する 女融點降下を來さボ.

Fp 252.5 の無突素性物質

德島産コクサギ根皮のオリキシン,コクサギン母液を硫酸々性となし佾殘你す べき鹽基抽出の目的にてアムモニア・アルカリ性となしクロロフ实ルムにて振盪 せしに該溶媒中に少量の結晶の 析出を見なり，酒精より再結晶の後獸炭添加の下 に更に水醋, 酒精より結晶せしめしものは少しく灰色を帶べる無色の板狀晶にし 
1056 寺阪：コクサギ Orixa japonica, Thunb. 根皮のアルカロイド研哭(第三報)

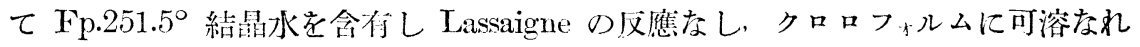
ぞ酒精, 氷醋に難溶にして水には熱時と踓溶け和冷アルカリに不浴なるど熱アル カリに溶解す, 又濃硫酸に無色に溶解す,冷時過マンガン酸加里を䏙芯せずFehling 氏液を還元せず Gaebel 氏反應陽性なり。

元素分析

\begin{tabular}{|c|c|c|c|c|c|}
\hline 物質 & $0.1029 \mathrm{~g}$ & $\mathrm{CO}_{2} 0.2859 \mathrm{~g}$ & $\mathrm{H}_{2} \mathrm{O} \quad 0.0502 \mathrm{~g}$ & $\mathrm{C}, 0622.52$ & Hós 5.46 \\
\hline , & $0.104 \% \mathrm{~g}$ & , $0.2398 \mathrm{~g}$ & $0.0540 \mathrm{~g}$ &, 62.70 &, 5.79 \\
\hline & $\mathrm{C}_{16} \mathrm{H}_{18} \mathrm{O}$ & ての理諭数 & &, 62.75 &, 5.26 \\
\hline
\end{tabular}

結晶水の定量

$$
\begin{array}{cccccc}
\text { 物質 } & 0.1088 \mathrm{~g} & \mathrm{H}_{2} \mathrm{O} & 0.0059 \mathrm{~g} & \mathrm{H}_{2} \mathrm{O}_{2} \% & 5.42 \\
” & 0.1044 \mathrm{~g} & \# & 0.0059 \mathrm{~g} & " & 5.66 \\
& \mathrm{C}_{16} \mathrm{H}_{18} \mathrm{O}_{6} & \text { としての理諭數 } & \# & 5.56
\end{array}
$$

分子量测定(Rast 法)

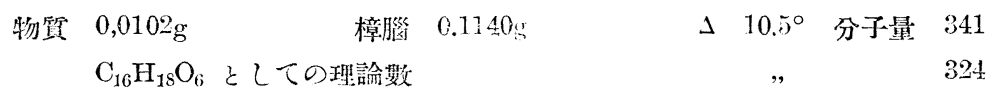

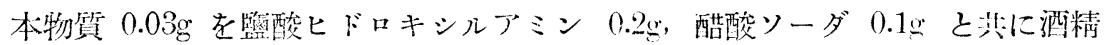
$10 \mathrm{cc}$ に溶解せしめ水浴上 4 時間加溫の後生成せる物管は F 2520 にして原物質 と異るなし。

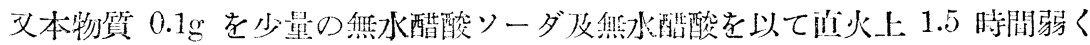

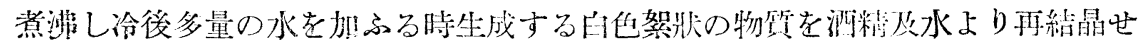

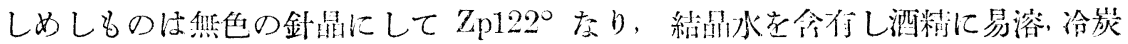

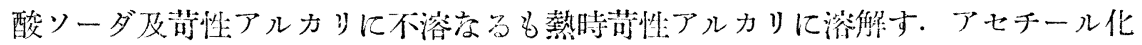
合物に他疗らざるべきも物質少量にして未杖分析するに真らず。

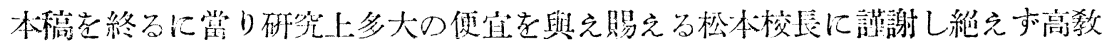

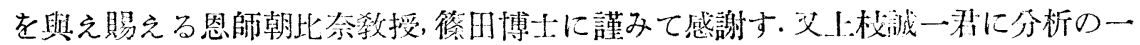

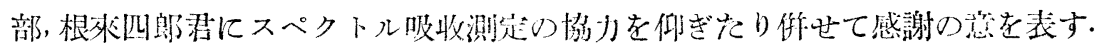

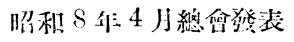

